\title{
Effect of Rainfall on Groundwater Level Fluctuation in Terengganu, Malaysia
}

Musa G. Abdullahi, ${ }^{1,2, *}$ and Iliyasu Garba ${ }^{3}$

${ }^{1}$ Department of Physics, Northwest University Kano, Nigeria

${ }^{2}$ East Coast Environmental Research Institute, University Sultan Zainal Abidin, Malaysia

${ }^{3}$ Department of Geology, Kano University of Science and Technology, Wudil Kano, Nigeria

\begin{abstract}
Water is substantial natural resources on earth which cater for all human endeavors. Groundwater is the most essential and reliable source of fresh water in every part of the world including an area with an excessive amount of rainfall and plentiful surface water. The study evaluates the effect of rainfall on groundwater level fluctuation using the rainfall, Evapotranspiration, and groundwater level fluctuation data from 2001 to 2013 in Terengganu Malaysia. These data were analyzed to show the rainfall variations, runoff, infiltration and groundwater fluctuation levels in different years. The analysis also illustrated that, the rainfall is influencing the groundwater level of the study area as the rain usually started in September and ended in December. However, there are little occurrences of rain in the rest of the months throughout the year. The maximum water level also was found during January to February due to the recharge by rainfall, runoff, and infiltration. The water table starts to decline from June to August and reaches its lowest level usually from August to September. The result also illustrates that, groundwater level decreased day by day due to mismanagement and unnecessary withdrawal from irrigation sectors and domestic uses.
\end{abstract}

Keywords: Rainfall; Runoff; Fluctuation; Infiltration; Groundwater table

\section{Introduction}

Malaysia is a country with many rivers and ocean crossed over it but, with all of this surface water cannot be relied upon for irrigation industrial and domestic uses. Some state uses groundwater as their source of irrigation, industry and domestic application among these states were the study area.

Groundwater refers to the water that occurs below the surface of the earth. It starts with rain and snow melt that seeps or infiltrates into the ground. The amount of water that seeps into the ground differs widely from place to place due to different types of land surface present. Groundwater is the purest form of water on the earth and found to be unlimited natural resources to mankind at the cheapest cost. It always flows through the fractures of rock and pore spaces over a long distance in the aquifers and to be available to the vast number of people at their firm [1].

Groundwater is free from air pollution and other pollutants that can easily pollute water from its pure form and wisely manage and protected against undue exploitation and contamination by the users Reddi 1986. Groundwater is dynamic natural resources that can be recharge most during the rainy season by the rainwater for the rest of the year. Over withdrawal of groundwater causes decline in the water table due to the stress and distorting the aquifer and may also leadadverse surface and subsurface environmental effect [2].

Groundwater recharge is usually influenced by climate variability and human intervention such as groundwater abstraction excessive or unsustainable withdrawal and the rest.

Siebert et al. [3] assessed groundwater use for irrigation in a global inventory via a range of pumping technologies. Recent studies in India and Bangladesh reported that a groundwater level (0.1-0.5 m/yr) was declining indicating reduction in aquifer storage for unsustainable groundwater abstraction for both irrigation and urban water supplies, this cases was also similar to Malaysia and other Asian countries.
Sayeed et al. [4] also assess groundwater recharge using Empirical method in the tropical zone (Selangor Malaysia) in which the groundwater recharge coefficient and effective rainfall were determined. The results showed that groundwater recharge was 326.39 $\mathrm{mm}$ per year, and recharge coefficient was found to be $18 \%$ for the study area. They further illustrated that unsustainable withdrawal can cause a decline in groundwater level.

The primary aim of this research is to evaluate the rainfall effect on groundwater level fluctuation in Terengganu Malaysia because of water demand is increasing rapidly due to increases in population growth and socioeconomic development. This encourage the current research in groundwater level so as the finding will provide some information to the government for water management and for predicting the future climatic event as well as groundwater level in order to avoid decline or shortage of it.

\section{Physiography, climate, and hydrogeology of the study area}

The study area is a state of the east coast of Peninsular Malaysia; it is situated in the coordinate $4^{\circ} 45^{\prime} \mathrm{N}$ latitude and $103^{\circ} 0^{\prime} \mathrm{E}$ longitude that is located in the north-eastern part of Peninsula Malaysia. Terengganu is bordered on the northwest by Kelantan, the southwest by Pahang and the east by South China Sea, the main river of the state is called River Terengganu. The state has a total area of $13,035 \mathrm{~km}^{2}(5,033$ sq. mi) and the total population of $1,015,776$ as for the 2010 census with a density of $78 \mathrm{~km}^{2}$ (200/sq. mi) $[5,6]$.

*Corresponding author: Musa G. Abdullahi, Department of Physics Northwest University Kano Nigeria, East Coast Environmental Research Institute, University Sultan Zainal Abidin, Malaysia, Tel: +60146456414; E-mail: musagarbaabdullahi@yahoo.com

Received February 26, 2015; Accepted March 27, 2015; Published April 03, 2015

Citation: Abdullahi MG, Garba I (2015) Effect of Rainfall on Groundwater Level Fluctuation in Terengganu, Malaysia. J Remote Sensing \& GIS 4: 142 doi:10.4172/2469-4134.1000142

Copyright: (c) 2015 Abdullahi MG, et al. This is an open-access article distributed under the terms of the Creative Commons Attribution License, which permits unrestricted use, distribution, and reproduction in any medium, provided the original author and source are credited. 
Climatically, like the other states of the country, Terengganu has tropical monsoon climate that is generally moderately hot and humid all year around. The temperature is relatively uniform within the range of $21^{\circ} \mathrm{C}$ to $32^{\circ} \mathrm{C}$ throughout the year. During the months of January to April, the weather is generally dry and warm. Humidity is consistently high which approximately $80 \%$. Terengganu has characterized by two main types of monsoon, usually the southwest monsoon season established in the latter half of May or early June and end in September. The northeast monsoon that usually starts in November and end in March. Terengganu receives heavy rainfall of approximately between $2034 \mathrm{~mm}$ to $2504 \mathrm{~mm}$ per year which can easily break the bank of the rivers and cause overbank discharge [7].

The aquifer in the study area is mostly covered with Indogangetic alluvium and is somehow deep. They are tapped primarily by private devices such as tube wells; pump sets rahats and the rest which are found mainly in the rural areas for their domestics used as well as for irrigation purposes. Some places have shallow aquifer ranges from 20 to 30 meters easy to dig for private purposes but for the state were dogs up to 100 to 130 meters. The groundwater fluctuation varies from place to place usually 0.2 to 0.8 meter between the pre-monsoon to postmonsoon season.

\section{Materials and Methods}

\section{Data collection}

The daily groundwater level data from seven hydrological stations collected from the Department of Minerals and Geosciences
Terengganu Malaysia for the period of 2001 to 2013 were sorted and arranged in an Excel for different homogeneity test. So also, the Evapotranspiration and rainfall data for the same years were collected from Department of Irrigation and Drainage (DID) and were sorted in the same format as above. And the map of the study area obtained from the Land and Survey Department Terengganu was used to locate the districts/stations were the data was obtained by the listed department above using GIS (Figure 1).

\section{Data quality}

The homogeneity of data (Rainfall, Runoff and Groundwater level) in this study was checked using the standard approaches such as Wijngaard et al. [8], Von Neumann ratio test and the Standard normal homogeneity test. All the data from these seven stations were found to be homogenous. The missing value were found to be less than $5 \%$ for the period 2000 to 2012, these missing values in the data series were estimated using various types of weighting methods such as inverse distance, correlation, and normal ratio.

\section{Runoff}

The portion of precipitation on land that ultimately reaches streams with dissolved or suspended materials is known as runoff. Water from rain and snow usually flows over the surface of the ground into the streams; this is the current collected from the drainage basin and appearing at an outlet of the basin. There is some contrast between precipitation and runoff; the runoff is more uniform compared to precipitation while the precipitation is sporadic and irregular in nature.

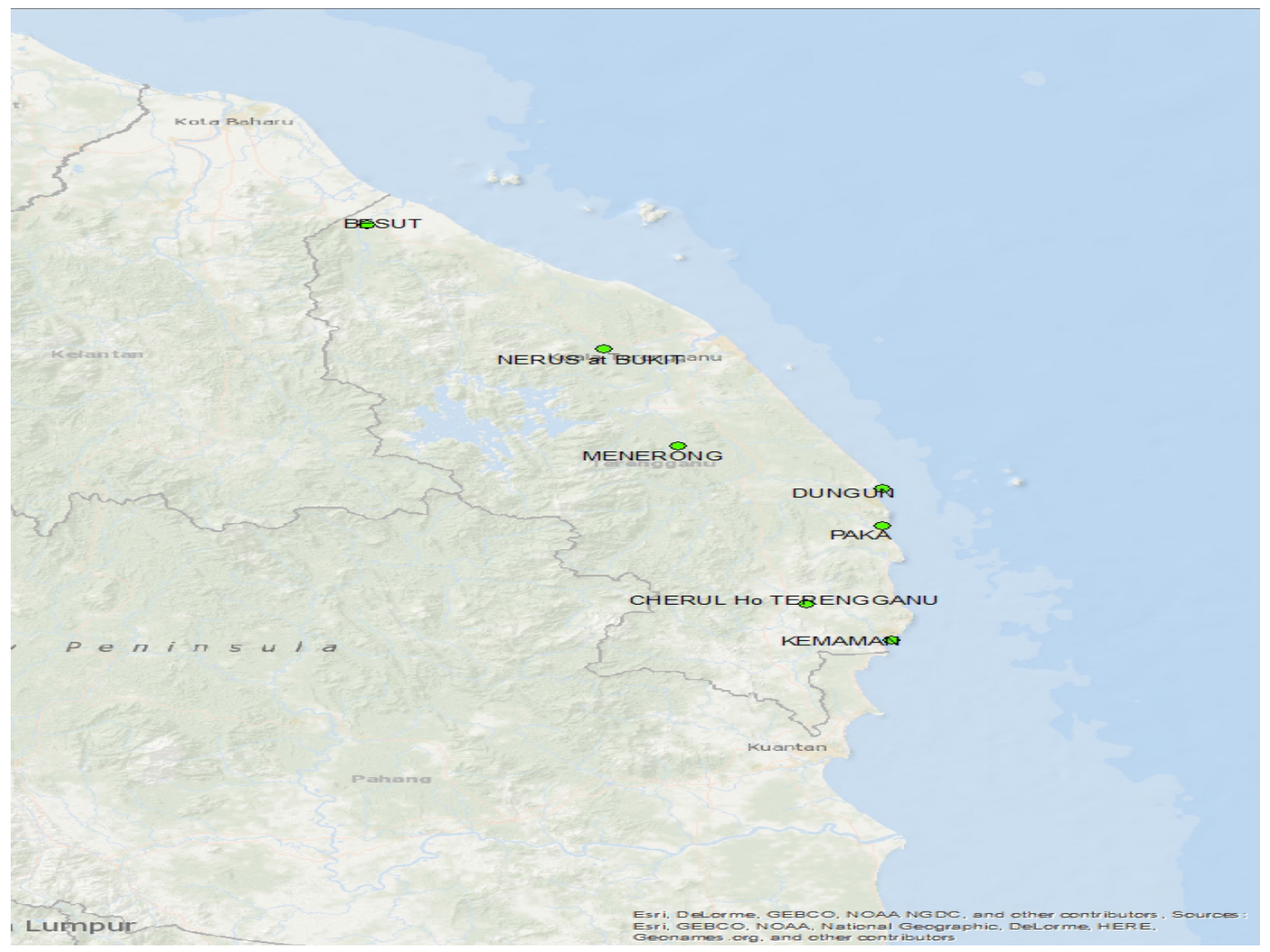

Figure 1: The map of the study area showing the district where the data was collected. 
Citation: Abdullahi MG, Garba I (2015) Effect of Rainfall on Groundwater Level Fluctuation in Terengganu, Malaysia. J Remote Sensing \& GIS 4: 142. doi:10.4172/2469-4134.1000142

Page 3 of 5

Runoff can be calculated using the following relation:

$$
R=K b^{*} P(1)
$$

Where, $\mathrm{Kb}$ and $\mathrm{P}$ are the rainfall and runoff coefficient, respectively.

\section{Infiltration}

The process by which water on the ground surface enters the soil that is governing by two forces: gravity and capillary action are known as infiltration. The water enters the surface starter of the earth. The infiltrated water first meets the soil moisture deficiency if any, and further the excess water moves vertically downwards to reach the groundwater table as recharge water. It is a measure of the rate at which soil is able to absorb rainfall or irrigation. During the infiltration, the rate decreases as the soil becomes fully saturated. Therefore, if the precipitation rate exceeds the infiltration rate runoff will usually occur unless there is some physical barrier. Infiltration can be calculated from equation (2):

$$
I=P-E T-R(2)
$$

Where, I, P, ET, and R indicate the infiltration, rainfall, evaporation, and runoff, respectively.

\section{Results and Discussions}

\section{Rainfall variation}

The monthly rainfall variations of seven Districts of the study area during 2001 to 2013 are shown in the (Figures 2-8). The maximum rainfall was found throughout September to January during the rainy season of the area. The minimum rainfall was observed from February to August and sometimes very little or none in some month between

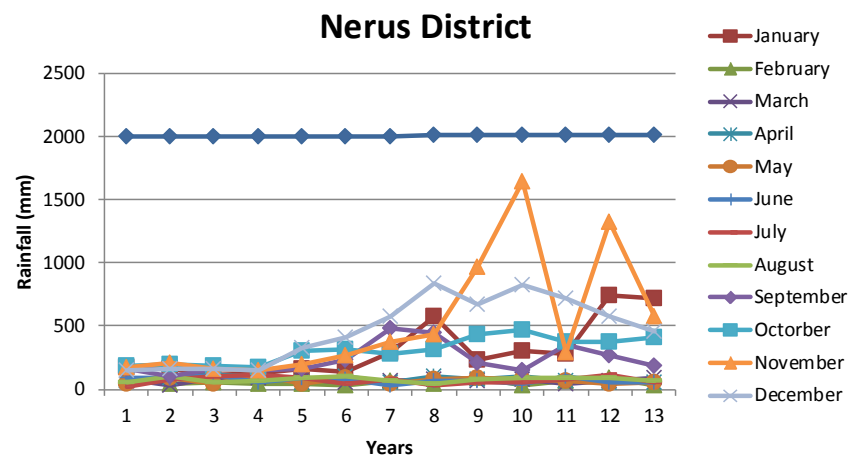

Figure 2: Monthly rainfall variations at Nerus District from 2001 to 2013.

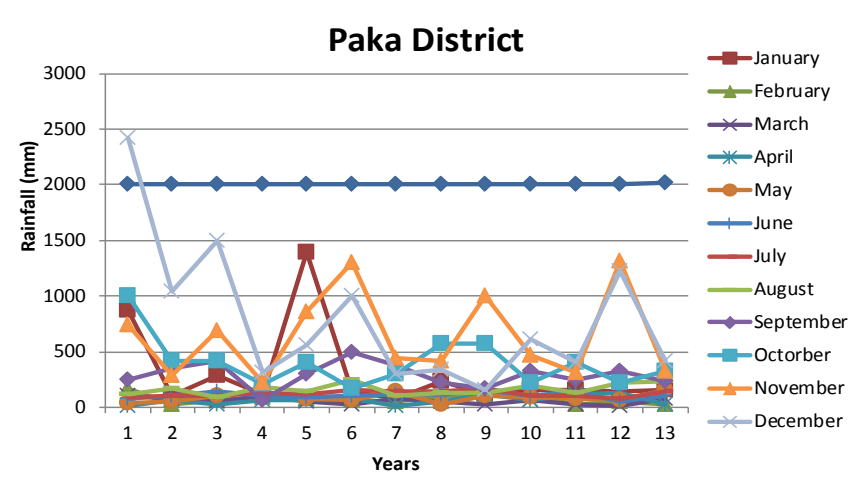

Figure 3: Monthly rainfall variations at Paka District from 2001 to 2013.

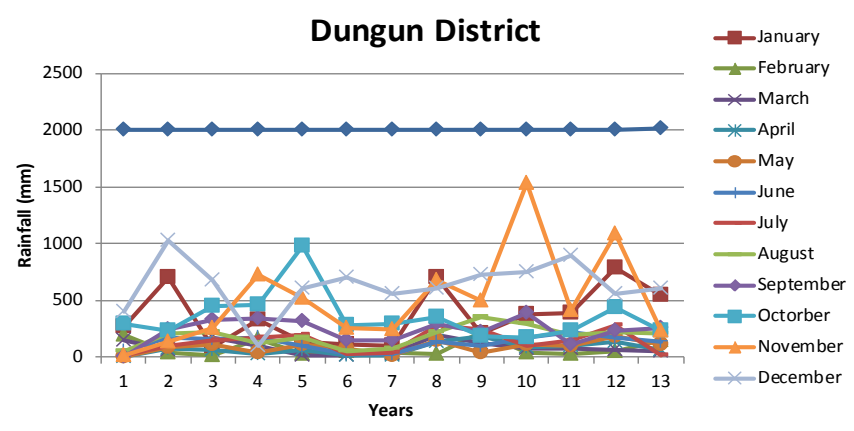

Figure 4: Monthly rainfall variations at Dungun District from 2001 to 2013.

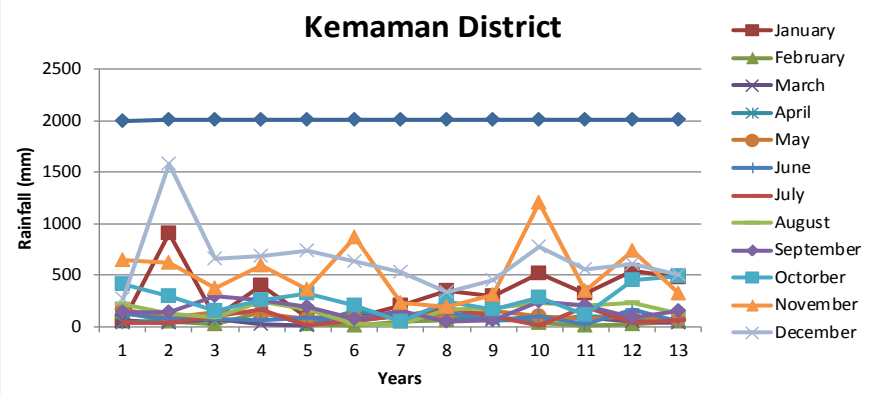

Figure 5: Monthly rainfall variations at Kemaman District from 2001 to 2013.

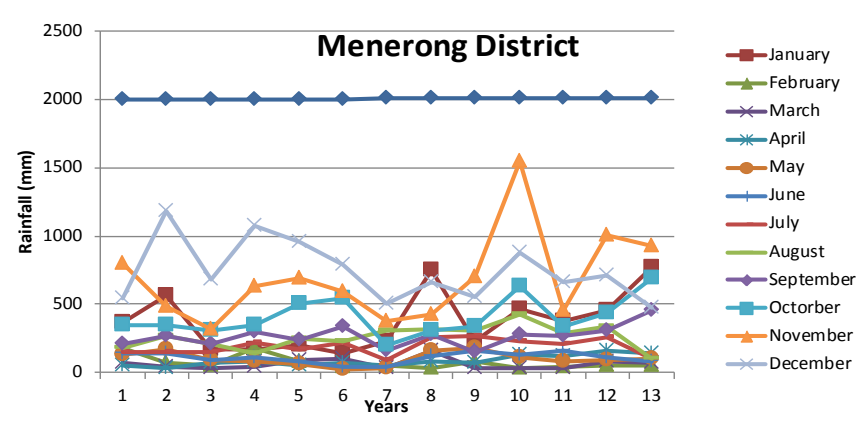

Figure 6: Monthly rainfall variations at Menerong District from 2001 to 2013.

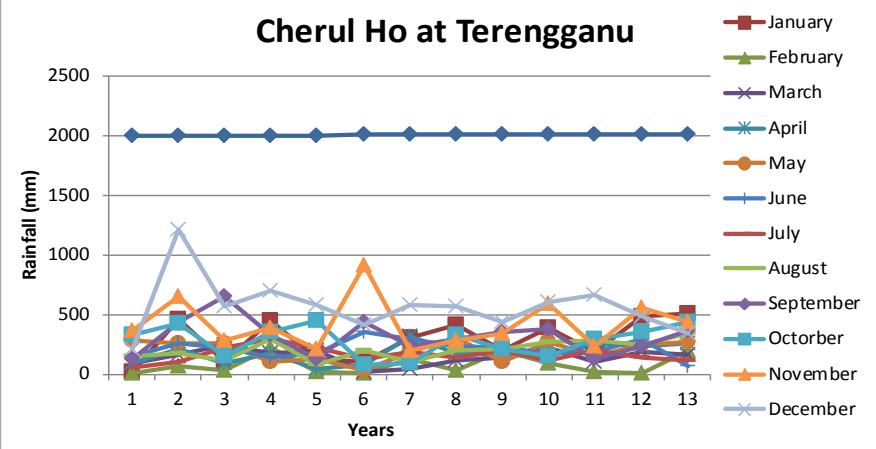

Figure 7: Monthly rainfall variations at Cherul District from 2001 to 2013.

these months. The results of the study entail that, the maximum rainfall was recorded at Nerus in November, 2009, Pakain December, 2001,Dungun in November,2009,Kemaman in December, 2001, Menerongin November, 2009, Cherul in December, 2001 and Besut in December, 2007. 


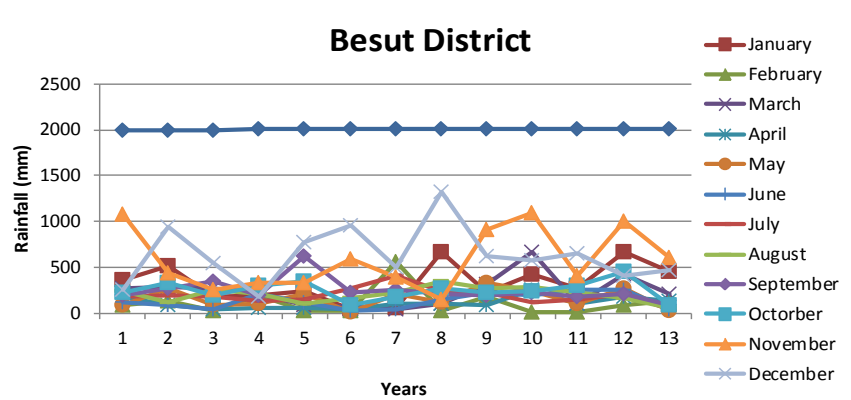

Figure 8: Monthly rainfall variations at Besut District from 2001 to 2013.

The maximum annual rainfall recorded at Paka was $3709 \mathrm{~mm}$ in 2001, Dungun $3994 \mathrm{~mm}$ in 2010,Kemaman, $4018 \mathrm{~mm}$ in 2002, Menerong, $4027 \mathrm{~mm}$ in 2010, Cherul, $3848 \mathrm{~mm}$ in 2012, Besut, $3942 \mathrm{~mm}$ in 2010 and at Nerus, $4012 \mathrm{~mm}$ in 2012. It indicated that Terengganu State received an excessive rainfall in the year 2010, as the rainfall recorded in each district shows the greater values. Menerong received the highest rainfall of $4027 \mathrm{~mm}$ in 2010 and Nerus received the lowest rainfall of $1101 \mathrm{~mm}$ in 2001 . While, the average rainfall received was recorded at Kemaman $(2722 \mathrm{~mm})$ in 2006 . The minimum annual rainfall has been registered atNerus $(1101 \mathrm{~mm})$ in the year 2001, and Nerus is the district that has the lowest rainfall in the area as the table above shown. The study result entailed that the rainfall is increased in the area since from 2001 to 2013, but the increases are not linearly. The rainfall data of the study area show a wide variation of rainfall depending on the area and year.

\section{Estimated runoff}

The results show that, the maximum estimated runoff was found in 2010 during the study period as the rainfall received was excessive. But throughout the study area, the estimated runoff was average and from 2010 to 2013 was gradually increasing as expected due to higher rainfall received during the years. The highest runoff estimated was $523 \mathrm{~mm}$ in 2010 in Menerong District, and the lowest runoff was $221 \mathrm{~mm}$ in 2001 at Nerus during the study period.

\section{Estimated infiltration}

The infiltration data of Trengganu, Malaysia illustrate that, the highest infiltration was estimated in 2010 during the study period as the maximum rainfall received during the year. Before the year 2010 the infiltration due some fluctuation and was average. The amount of infiltration was increased from 2010 to 2013 but did not reach the highest values obtained in 2010. The estimated highest infiltration was $3645 \mathrm{~mm}$ in 2010 at Menerong, and the lowest was $980 \mathrm{~mm}$ in 2001 at Nerus.

\section{Relationship between rainfall and water level fluctuation}

The result of the analysis entailed that, annual rainfall of the state is increases but not linear and decreases in 2013 for the study period as recorded in Table 1. Similarly for runoff and infiltration data in Tables 2 and 3 above, this result shows a good relationship among the parameters which indicate that, the higher the value was the rainfall, the higher amount where the estimated runoff and infiltration (Table 4).

The above (Figure 9) illustrates the trends in the water table of the study area during 2001 to 2012. The result showed that, the minimum water table was in 2005, and the maximum was in 2011 due to different in rainfall, infiltration, and runoff. The result indicated the good relationship between these parameters as the fluctuation curve indicated which was abiding by the nature of the rainwater of the area. The highest deflection occurred from April to August, and the water table slowly increased until it reached the minimum during September to November it maintained an average level until February.

\begin{tabular}{|c|c|c|c|c|c|c|c|}
\hline Year & $\begin{array}{c}\text { Paka } \\
(\mathrm{mm})\end{array}$ & $\begin{array}{c}\text { Dungun } \\
(\mathrm{mm})\end{array}$ & $\begin{array}{c}\text { Kemaman } \\
(\mathrm{mm})\end{array}$ & $\begin{array}{c}\text { Menerong } \\
(\mathrm{mm})\end{array}$ & $\begin{array}{c}\text { Cherul } \\
(\mathrm{mm})\end{array}$ & $\begin{array}{c}\text { Besut } \\
(\mathrm{mm})\end{array}$ & $\begin{array}{c}\text { Nerus } \\
(\mathrm{mm})\end{array}$ \\
\hline 2001 & 3709 & 1124 & 2704 & 3988 & 1871 & 3188 & 1101 \\
\hline 2002 & 2560 & 3523 & 4018 & 3820 & 3826 & 3631 & 1147 \\
\hline 2003 & 2650 & 2704 & 2295 & 2877 & 2286 & 2423 & 1149 \\
\hline 2004 & 2283 & 2867 & 3229 & 3878 & 3529 & 2331 & 1393 \\
\hline 2005 & 3201 & 3069 & 2096 & 3582 & 2360 & 2113 & 1730 \\
\hline 2006 & 2870 & 1971 & 2722 & 1370 & 2204 & 2589 & 2181 \\
\hline 2007 & 2558 & 1252 & 2149 & 1235 & 2970 & 2934 & 3790 \\
\hline 2008 & 2553 & 3990 & 2437 & 3860 & 3076 & 3713 & 3895 \\
\hline 2009 & 3333 & 3423 & 2616 & 3640 & 2767 & 3825 & 3960 \\
\hline 2010 & 2904 & 3994 & 4001 & 4027 & 3496 & 3942 & 3972 \\
\hline 2011 & 1901 & 3162 & 2144 & 3524 & 2701 & 2758 & 3064 \\
\hline 2012 & 2421 & 3801 & 3716 & 3920 & 3848 & 3845 & 4012 \\
\hline 2013 & 1910 & 1477 & 1225 & 2022 & 2061 & 1957 & 1918 \\
\hline
\end{tabular}

Table 1: Annual rainfall of seven districts in Terengganu Malaysia, during, 2001 to 2013 .

\begin{tabular}{|c|c|c|c|c|c|c|c|}
\hline Year & $\begin{array}{c}\text { Paka } \\
(\mathrm{mm})\end{array}$ & $\begin{array}{c}\text { Dungun } \\
(\mathrm{mm})\end{array}$ & $\begin{array}{c}\text { Kemaman } \\
(\mathrm{mm})\end{array}$ & $\begin{array}{c}\text { Menerong } \\
(\mathrm{mm})\end{array}$ & $\begin{array}{c}\text { Cherul } \\
(\mathrm{mm})\end{array}$ & $\begin{array}{c}\text { Besut } \\
(\mathrm{mm})\end{array}$ & $\begin{array}{c}\text { Nerus } \\
(\mathrm{mm})\end{array}$ \\
\hline 2001 & 345 & 245 & 321 & 365 & 232 & 311 & 221 \\
\hline 2002 & 289 & 278 & 298 & 311 & 265 & 321 & 233 \\
\hline 2003 & 290 & 324 & 300 & 276 & 234 & 320 & 243 \\
\hline 2004 & 300 & 341 & 279 & 256 & 276 & 298 & 276 \\
\hline 2005 & 287 & 322 & 312 & 298 & 321 & 311 & 289 \\
\hline 2006 & 299 & 300 & 278 & 312 & 233 & 299 & 278 \\
\hline 2007 & 289 & 278 & 263 & 406 & 243 & 300 & 300 \\
\hline 2008 & 279 & 289 & 277 & 416 & 221 & 308 & 311 \\
\hline 2009 & 268 & 298 & 287 & 477 & 242 & 320 & 321 \\
\hline 2010 & 300 & 300 & 290 & 523 & 247 & 312 & 323 \\
\hline 2011 & 305 & 302 & 294 & 501 & 299 & 322 & 343 \\
\hline 2012 & 311 & 308 & 300 & 508 & 301 & 324 & 340 \\
\hline 2013 & 320 & 321 & 302 & 511 & 311 & 342 & 228 \\
\hline
\end{tabular}

Table 2: Estimated runoff of seven districts of Terengganu, Malaysia during 2001 to 2013 .

\begin{tabular}{|c|c|c|c|c|c|c|c|}
\hline Year & $\begin{array}{c}\text { Paka } \\
(\mathrm{mm})\end{array}$ & $\begin{array}{c}\text { Dungun } \\
(\mathrm{mm})\end{array}$ & $\begin{array}{c}\text { Kemaman } \\
(\mathrm{mm})\end{array}$ & $\begin{array}{c}\text { Menerong } \\
(\mathrm{mm})\end{array}$ & $\begin{array}{c}\text { Cherul } \\
(\mathrm{mm})\end{array}$ & $\begin{array}{c}\text { Besut } \\
(\mathrm{mm})\end{array}$ & $\begin{array}{c}\text { Nerus } \\
(\mathrm{mm})\end{array}$ \\
\hline 2001 & 3005 & 2495 & 3210 & 3165 & 2312 & 3011 & 980 \\
\hline 2002 & 2189 & 2878 & 2298 & 3011 & 2655 & 2321 & 1033 \\
\hline 2003 & 2190 & 3024 & 3200 & 2746 & 2345 & 3220 & 1243 \\
\hline 2004 & 3100 & 3001 & 2179 & 3256 & 2376 & 2198 & 2716 \\
\hline 2005 & 2877 & 3122 & 3112 & 2398 & 3121 & 3111 & 2189 \\
\hline 2006 & 2299 & 3010 & 2780 & 3312 & 2323 & 2299 & 2718 \\
\hline 2007 & 2829 & 2728 & 2263 & 2306 & 2423 & 3020 & 2010 \\
\hline 2008 & 2749 & 2829 & 2727 & 2416 & 2221 & 3018 & 1011 \\
\hline 2009 & 2468 & 2298 & 2827 & 3002 & 2242 & 3120 & 2121 \\
\hline 2010 & 3100 & 3100 & 2990 & 3645 & 3247 & 3122 & 2123 \\
\hline 2011 & 3205 & 3102 & 3080 & 3444 & 3290 & 3124 & 2143 \\
\hline 2012 & 3311 & 3108 & 3090 & 3536 & 3201 & 3124 & 2140 \\
\hline 2013 & 3212 & 3110 & 3019 & 3240 & 3021 & 3031 & 2144 \\
\hline
\end{tabular}

Table 3: Estimated infiltration of seven districts of Terengganu, Malaysia during 2001 to 2013. 
Citation: Abdullahi MG, Garba I (2015) Effect of Rainfall on Groundwater Level Fluctuation in Terengganu, Malaysia. J Remote Sensing \& GIS 4: 142. doi:10.4172/2469-4134.1000142

Page 5 of 5

\begin{tabular}{|c|c|c|c|}
\hline Year & Rainfall $(\mathrm{mm})$ & Runoff $(\mathrm{mm})$ & Infiltration $(\mathrm{mm})$ \\
\hline 2001 & 2526 & 291 & 2597 \\
\hline 2002 & 3218 & 285 & 2341 \\
\hline 2003 & 2341 & 284 & 2567 \\
\hline 2004 & 2787 & 289 & 2689 \\
\hline 2005 & 2593 & 306 & 2847 \\
\hline 2006 & 2272 & 286 & 2677 \\
\hline 2007 & 2413 & 297 & 2511 \\
\hline 2008 & 3361 & 300 & 2424 \\
\hline 2009 & 3366 & 316 & 2583 \\
\hline 2010 & 3762 & 328 & 3047 \\
\hline 2011 & 2750 & 338 & 3055 \\
\hline 2012 & 3652 & 342 & 3073 \\
\hline 2013 & 1795 & 334 & 2968 \\
\hline
\end{tabular}

Table 4: The average annual rainfall, runoff and infiltration of Terengganu, Malaysia during 2001 to 2013.

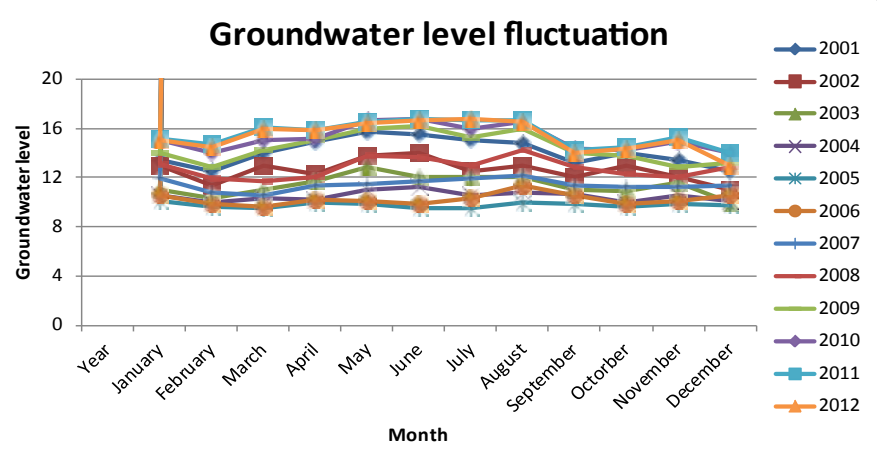

Figure 9: Water table fluctuations of Terengganu, Malaysia during 2001 to 2012.

The water table starts to decreases till the heavy rain will start again in September. However, the overall yearly water table result indicating decline in groundwater level trend is due to unsustainable withdrawal of groundwater for domestic and irrigation purposes as the state used groundwater for water supply, this were played a vital role in water level fluctuation in Terengganu, Malaysia.

\section{Conclusion}

The study results illustrate that, the maximum rainfall occurred during October to December, and little rainfall was recorded during
January to September. However, the maximum runoff and infiltration were also estimated during October to December. The water table fluctuation was recorded monthly, and analysis showed that, rainfall, runoff, and infiltration have an influence in recharge of the water table in Terengganu, Malaysia. The water table elevated during January to February due to the recharge by the listed parameters and usually declined from June to August. The lowest level of groundwater level fluctuation was found to be from August to September. The result of this study entails that the groundwater level fluctuations in Terengganu is depended solidly on rainfall pattern. The findings of this research can provide some information to the government for water management and for predicting future climatic events.

\section{Acknowledgement}

Authors are thankful to the Department of Irrigation and Drainage and Department of Minerals and Geosciences Terengganu Malaysia for providing the data on this work. Authors acknowledge the Postgraduate school Universiti Sultan ZainalAbidin for the provision of transportation for the site visit and data collection.

\section{References}

1. Backundukize $C$, Van Camp M, Walraevans K (2011) Estimation of groundwate recharge in Bugesera region (Burindi) Using soil moisture budget approach Gelogica Belgica 14: 85-120.

2. Hasan MR, Mostafa MG, Matin I (2003) Effect of Rainfall on Groundwater level Fluctuation in Chapai Nawabgonj District. International Journal of Engineering Research and Technology 2:2800-2807.

3. Siebert S, Burke J, Faures JM, Frenken K, Hoogeveen J, et al. (2010) Groundwater uses for Irrigation- a global inventory. Hydrol. Earth Syst 14: 1863-1880.

4. Sayeed RS, Ismail Y, Sa'ari M, Sayeed FS (2013) Estimation of ground water level using Empirical method: A case study in the Tropical zone. Sains Malaysiana 42: 553-560.

5. Laporan KP (2010) Jabatan Perankaan Malaysia P.27 Achieved from the original on 2010-12-27 Retrieved 2011-01-24.

6. Data Asas Negeri (2006) Perancang Ekonomi Negeri, 2006. Achieved from the original on 2007-12-17 Retrieved 2008-01-06.

7. Musa GA Muhd ET, Muhd BG, Hafizan J (2014) Rainfall Dynamics of Terengganu, Malaysia and its Recent Trends Analysis Using Mann-Kendall Test. Journal of Advances in Biotechnology 4: 374-381.

8. Wijngaard JB, Klein Tank AMG, Konnen GP (2003) Homogeneity of $20^{\text {th }}$ century European daily temperature and precipitation series, International Journal of Climatology 21: 679-692. 